\title{
Paclitaxel: new uses for an old drug
}

This article was published in the following Dove Press journal:

Drug Design, Development and Therapy

20 February 2014

Number of times this article has been viewed

\section{Dongshan Zhang',2 \\ Ruhao Yang' \\ Shixuan Wang ${ }^{2}$ \\ Zheng Dong',2}

'Departments of Emergency Medicine and Nephrology, Second Xiangya Hospital, Central South University, Changsha, Hunan, People's Republic of China; ${ }^{2}$ Department of Cellular Biology and Anatomy, Medical College of Georgia, Georgia Regents University and Charlie Norwood VA Medical Center, Augusta, GA, USA
Correspondence: Zheng Dong Department of Nephrology, Second Xiangya Hospital, Central South University, Changsha, Hunan, People's Republic of China

Tel +8673185292064

Fax $+8673 \mid 85292060$

Email zdong@gru.edu
Abstract: Paclitaxel (Taxol), one of the most important anticancer drugs, has been used for therapy of different types of cancers. Mechanistically, paclitaxel arrests cell cycle and induces cell death by stabilizing microtubules and interfering with microtubule disassembly in cell division. Recently, it has been found that low-dose paclitaxel seems promising in treating non-cancer diseases, such as skin disorders, renal and hepatic fibrosis, inflammation, axon regeneration, limb salvage, and coronary artery restenosis. Future studies need to understand the mechanisms underlying these effects in order to design therapies with specificity.

Keywords: taxol inflammation, fibrosis, coronary artery restenosis, limb salvage, kidney

\section{Introduction}

Taxol, a natural diterpene alkaloid (Figure 1), was originally isolated from the bark of Taxus brevifolia tree in the western region of the United States. When it was commercially developed by the Bristol-Myers Squibb (BMS; New York, NY, USA) Taxol was renamed to paclitaxel. Melting point of paclitaxel is around $216^{\circ} \mathrm{C}-217^{\circ} \mathrm{C}$, and it has highly lipophilic, low water solubility; higher protein binding rate; and mainly disturbs the structure of the inner part of the cell membrane. ${ }^{1,2}$ The role of paclitaxel has been the subject of study on anticancer agents for almost half a century. It is one of the most widely used anticancer drugs, and has been used for the treatment of various cancers from metastatic breast cancer, advanced ovarian cancer, non-small-cell lung cancer, to Kaposi's sarcoma. ${ }^{3,4}$ Recent studies, however, have demonstrated using low-dose paclitaxel to treat non-cancer human diseases, such as skin disorders, renal and hepatic fibrosis, inflammation, axon regeneration, limb salvage, and coronary artery restenosis ${ }^{5-12}$ (Figure 2).

\section{Basic mechanism of the anti-cancer effect of paclitaxel}

Paclitaxel belongs to the family of cytoskeletal drugs that target tubulin. As a result, paclitaxel treatment leads to abnormality of the mitotic spindle assembly, chromosome segregation, and consequently defects of cell division. By stabilizing the microtubule polymer and preventing microtubules from disassembly, paclitaxel arrests cell cycle in the $\mathrm{G}_{0} / \mathrm{G}_{1}$ and $\mathrm{G}_{2} / \mathrm{M}$ phases and induces cell death in cancer ${ }^{13-14}$ (Figure 3 ). It has been known that inhibition of mitotic spindle using paclitaxel usually depends on its suppression of microtubule dynamics. ${ }^{15}$ However, recent studies demonstrated that only low-dose paclitaxel can do so, in contrast, high-dose paclitaxel might suppress 


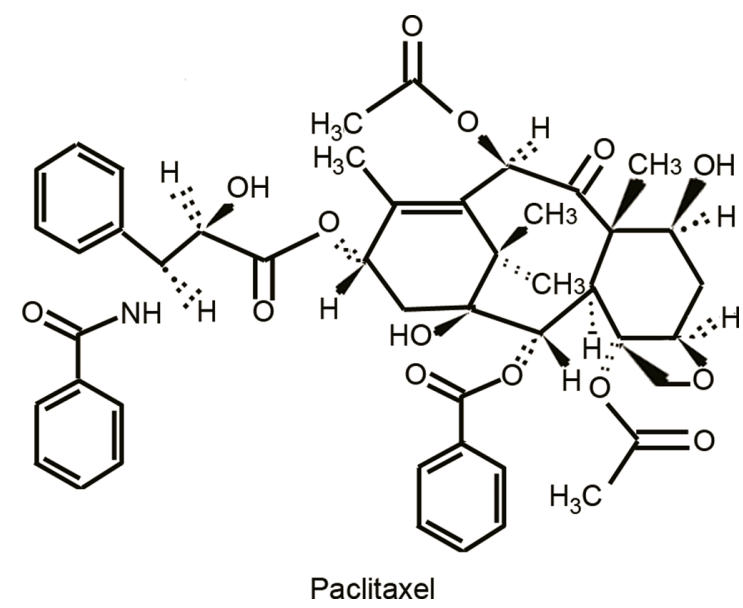

Figure I Chemical structure of paclitaxel.

microtubule detachment from the centrosomes. ${ }^{16}$ The binding site for paclitaxel has been identified to be the subunit of beta-tubulin. ${ }^{17}$ Paclitaxel has other mechanisms of action than for microtubule targeting. Panis et $\mathrm{al}^{18}$ found that the breast cancer patients after acute paclitaxel treatment exhibited immunosuppressive status by a strong type 2 helper T-cell (Th2) profile demonstrated by high levels of interleukin (IL)10. Alexandre et $\mathrm{al}^{19}$ and Hadzic et $\mathrm{al}^{20}$ reported paclitaxel induced reactive oxygen species generation by enhancing the activity of nicotinamide adenine dinucleotide phosphate (NADPH) oxidase, which contributed to the potent anticancer activity of paclitaxel. The antineoplastic mechanisms to the non-chemotherapeutic use of paclitaxel were found. For example, Sevko et al ${ }^{21,22}$ reported that paclitaxel enhanced the efficacy of chemotherapy by blocking the immunosuppressive potential of myeloid-derived suppressor cells. Gan et al ${ }^{23}$

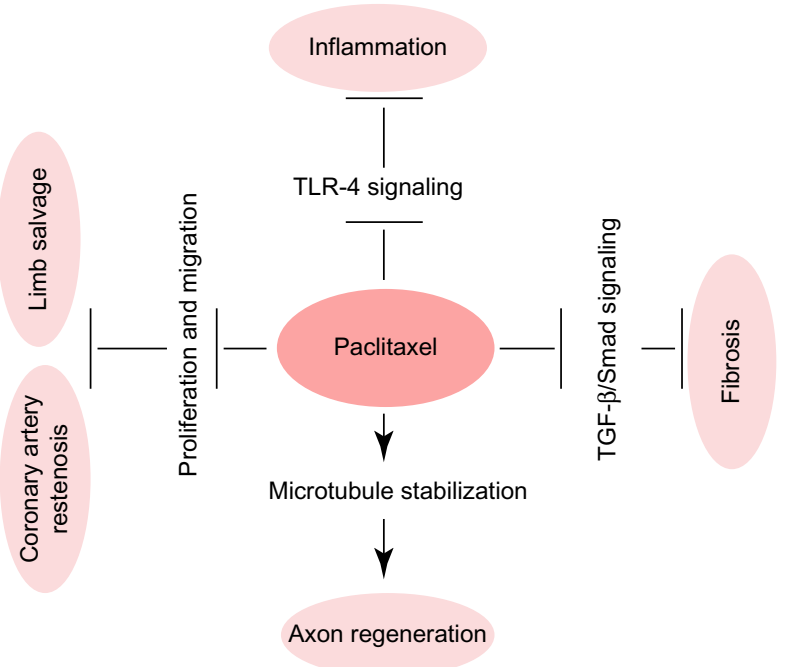

Figure 2 Reported effects of paclitaxel in non-cancer diseases. Abbreviations: TLR-4, toll-like receptor 4;TGF- $\beta$, transforming growth factor-beta.

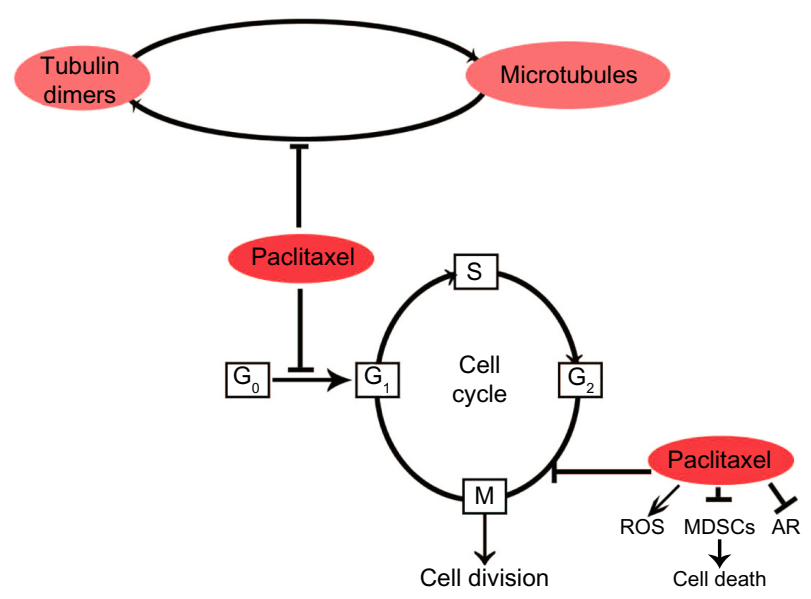

Figure 3 Anti-cancer actions of paclitaxel.

Note: By stabilizing microtubules, paclitaxel arrests cell cycle in the $G_{0} / G_{1}$ and $G_{2} / M$ phases and induces cell death.

Abbreviations: ROS, reactive oxygen species; MDSCs, myeloid-derived suppressor cells; $A R$, androgen receptor.

discovered that paclitaxel inhibited the androgen receptor by inducing nuclear accumulation of FOXO1 (forkhead box protein O1) as one of the anticancer mechanisms (Figure 3).

\section{Treatment of fibrotic diseases}

Transforming growth factor-beta (TGF- $\beta$ ) is one of the most important profibrotic growth factors, which can bind to and activate cell surface-specific receptors and in turn promotes diverse cellular responses. The activated TGF- $\beta$ receptors activate mothers against decapentaplegic homolog (Smad)2 and Smad3 proteins, which further form a protein complex with Smad4. This protein complex then translocates from the cytoplasm into the nucleus to regulate the transcription of target genes. ${ }^{24}$ It has been reported that in some cell lines, binding of endogenous Smad2, Smad3 and Smad4 to microtubules negatively modulates TGF- $\beta$ activity. ${ }^{25}$ Paclitaxel, by stabilizing microtubules, may therefore be inhibitory to TGF- $\beta$ signaling in fibrosis (Figure 4). Interestingly, low-dose paclitaxel has been shown to inhibit collagen-induced arthritis, hepatic fibrosis, and fibrosis associated with systemic sclerosis in severe combined immunodeficiency (SCID) mice. ${ }^{5-6,26}$ In kidneys, Zhang et $\mathrm{al}^{7}$ reported that low-dose paclitaxel $(0.3 \mathrm{mg} / \mathrm{kg}$, twice a week) significantly reduced tubulointerstitial fibrosis in a rat model of unilateral ureteral obstruction. Karbalay-Doust et a ${ }^{27}$ found that both taurine and paclitaxel $(0.3 \mathrm{mg} / \mathrm{kg} / \mathrm{d})$ had a renoprotective role in the unilateral ureteral obstruction model and the latter was more effective. Following subtotal renal ablation in rats, low-dose paclitaxel $(0.3 \mathrm{mg} / \mathrm{kg}$, twice a week $)$ showed a significant renoprotective role by modulating TGF- $\beta / \mathrm{Smad} / \mathrm{miR}-192$ signaling. ${ }^{8}$ In respect of lungs, Wang et $\mathrm{al}^{28}$ recently reported that low-dose paclitaxel $(0.6 \mathrm{mg} / \mathrm{kg} / \mathrm{d})$ reduced pulmonary fibrosis in rat (bleomycin) BLM-instilled pulmonary fibrosis 


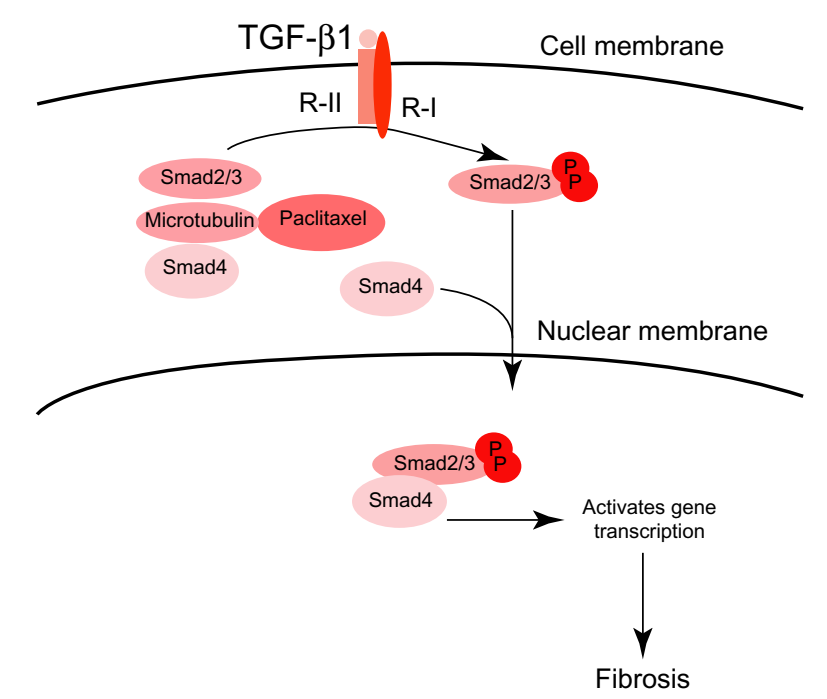

Figure 4 Paclitaxel inhibits TGF- $\beta /$ Smad signaling via enhancing endogenous Smad2, Smad3 and Smad4 binding to microtubules, and thereby ameliorates fibrosis. Abbreviations: TGF- $\beta$, transforming growth factor-beta; Smad, mothers against decapentaplegic homolog; $\mathrm{p}$, phosphorylated; R-I, TGF $\beta$ receptor I; R-II, TGF $\beta$ receptor II.

model. In this model, paclitaxel blocked the TGF- $\beta 1 / \mathrm{Smad} 3$ pathway via up regulation of miR-140. Interestingly, low-dose paclitaxel $(5-10 \mathrm{nM})$ also reduced stromal fibrosis in gastric cancer. ${ }^{29}$ High-dose paclitaxel $\left(175 \mathrm{mg} / \mathrm{mm}^{2}\right)$ may inhibit tumor cell proliferation, however, some cancer patients with prolonged paclitaxel $\left(175 \mathrm{mg} / \mathrm{mm}^{2}\right)$ treatment suffered from sclerodermalike changes or pulmonary fibrosis. ${ }^{30-33}$ These results suggest that low-dose paclitaxel has the potential to treat or prevent tissue fibrosis in experimental animal models, but more work is needed to carefully assess the effect in human patients.

\section{Regulation of inflammation}

It was reported that paclitaxel attenuated tumor necrosis factor (TNF)- $\alpha$ and thrombin-induced solute permeability, by enhancing the endothelial monolayer and paracellular gap junction formation. ${ }^{34,35}$ Paclitaxel $(10,25$, and $50 \mu \mathrm{g} / \mathrm{mL})$ also decreased leukocyte transmigration through endothelial monolayers by stabilization of endothelial microtubules. ${ }^{36}$ Pretreatment with paclitaxel (5-10 M) markedly inhibited chemotaxis induced by endotoxin-activated serum. ${ }^{37}$ Moreover, paclitaxel (plasma concentration of $10 \mu \mathrm{M}$ ) was shown to attenuate the vascular leak and inflammation in lipopolysaccharide (LPS)-induced acute lung injury in a mouse model. ${ }^{9}$ However, the molecular mechanism underlying the inhibitory effect of paclitaxel on inflammation is not fully understood. One study indicated that, like LPS, paclitaxel $(\geq 5 \mu \mathrm{M})$ was able to activate nuclear factor-

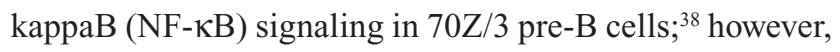
pretreatment with paclitaxel might completely inhibit LPS-induced NF-KB activation, ${ }^{38}$ suggesting that LPS and paclitaxel may share and compete for a common receptor/ signaling pathway. ${ }^{39,40}$ LPS can directly interact with tolllike receptor (TLR)-4-associated MD-2 which has a critical role in LPS recognition. ${ }^{41}$ Of note, in murine cells and tissues the effect of paclitaxel is highly dose-dependent. At $3 \mu \mathrm{M}$ or lower concentrations, paclitaxel binds to MD-2 to block TLR-4 signaling and inflammation in murine cells as human cells; however at $3.25 \mu \mathrm{M}$ or higher concentrations, paclitaxel binding to murine MD-2 promoted inflammation by activation of MD-2/TLR-4 $4^{42,43}$ (Figure 5). Our recent research demonstrated that paclitaxel at $2 \mu \mathrm{M}$ had a significant protective effect in kidneys by competitive binding to MD-2 to block MD-2/TLR-4 signaling during LPS treatment, resulting in the suppression of NF- $\mathrm{KB}$ activation and pro-inflammatory cytokine production. ${ }^{44}$ Use of low-dose paclitaxel may therefore offer a treatment for inflammatory diseases including sepsis and related complications.
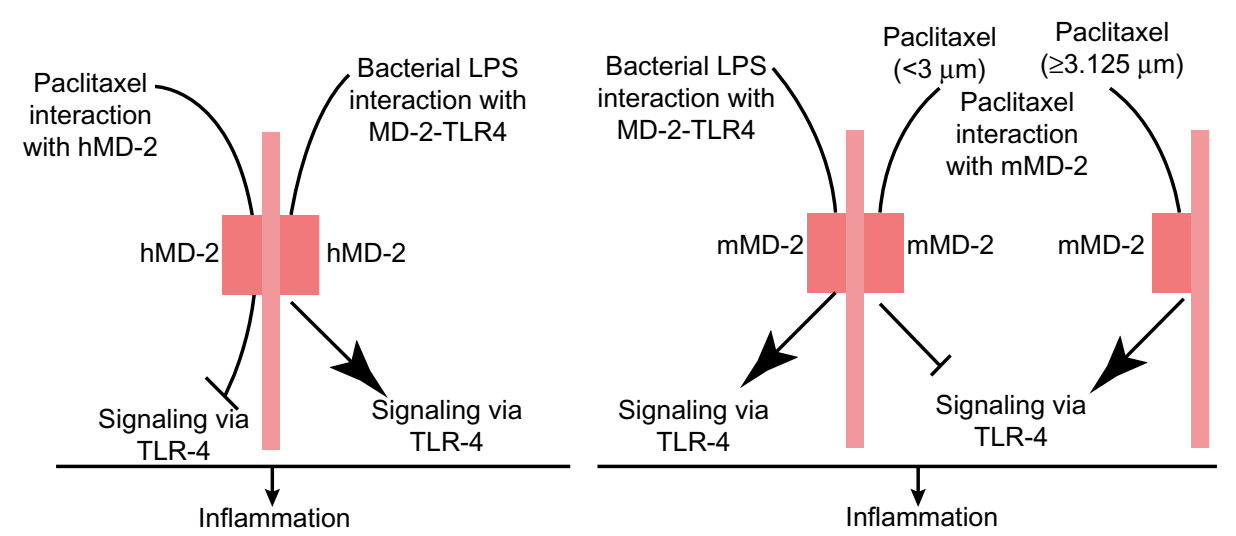

Figure 5 Paclitaxel inhibits inflammation by blocking TLR-4 signaling via binding to MD-2.

Notes: Binding of paclitaxel $(\geq 3.125 \mu \mathrm{M})$ to murine MD-2 results in the activation of MD-2/TLR-4 and promotes inflammation, whereas binding of paclitaxel to human MD-2, does not.

Abbreviations: TLR-4, toll-like receptor 4; LPS, lipopolysaccharide; hMD-2, human MD-2; mMD-2, mouse MD-2. 


\section{Facilitation of axon regeneration in injured central nervous system}

Poor regeneration of damaged axons in traumatic injuries of the central nervous system (CNS) usually causes permanent, devastating disabilities. Sengottuvel et $\mathrm{al}^{45}$ demonstrated that low-dose paclitaxel $(1,10,100$, and $1,000 \mu \mathrm{M})$ treatment enabled axons to regenerate without affecting the intrinsic regenerative state of mature retinal ganglion cells in rats. Furthermore, paclitaxel treatment promoted lens injurymediated axon regeneration by microtubule stabilization in the growth cone. The beneficial effects of paclitaxel were accompanied by a reduction of the infiltration of macrophages and a delay in glial scar formation at the injury site. These findings are supported by another study, which demonstrated that paclitaxel (256 ng/day) could reduce fibrotic scarring and enhance the capacity of axons to grow after spinal cord injury in rodents. ${ }^{10}$ Mechanistically, it was suggested that paclitaxel may reduce accumulation of some inhibitory substances from scar tissue by dampening TGF- $\beta$ signaling. ${ }^{10}$ These data suggest that paclitaxel may be beneficial in facilitating axon regeneration in different areas of the CNS.

\section{Paclitaxel use in critical limb ischemia}

Critical limb ischemia (CLI) typically presents as rest pain, tissue ulceration, or frank tissue loss with gangrene, often accompanied by infection. A clinical trial tested the effect of local paclitaxel application on restenosis, a disease condition of narrowing of blood vessels leading to restricted blood flow. In this study, 154 patients with stenosis were randomly divided into three groups for treatment with balloon; bare balloon with paclitaxel dissolved in contrast media; or a paclitaxel-coated balloon $\left(3 \mu \mathrm{g} / \mathrm{mm}^{2}\right)$. The late lumen loss was significantly lower in the group treated with paclitaxelcoated angioplasty balloons. ${ }^{11}$ Similarly, in another study, 87 patients were randomized to bare balloon and paclitaxel (3 $\mu \mathrm{g} / \mathrm{mm}^{2}$ )-coated balloon groups. Both late lumen loss and target lesion revascularization were significantly lower in the paclitaxel-coated balloon-treated patients. ${ }^{46}$ In a third study, 29 patients with 32 limbs with CLI were treated by infrapopliteal application of paclitaxel-eluting stents (PES) procedures and acceptable clinical results were achieved in CLI, although they failed to prevent vascular restenosis and reduce repeat interventions. ${ }^{47}$ In a fourth study, 104 patients were treated with paclitaxel-eluting balloons (PEBs), compared with historical data using uncoated balloons, the early restenosis rate of long-segment infrapopliteal disease was significantly lower. ${ }^{48}$ Furthermore, paclitaxel delivered by drug-coated balloons or drug-eluting stents enhanced durability of lower extremity endovascular procedures, and had a particular benefit for diabetic limb salvage. ${ }^{49}$ Mechanically, paclitaxel has a role in anti-proliferation and migration for muscle smooth cells. ${ }^{49}$ Together, these clinical trials have demonstrated the beneficial effect of paclitaxel in treating stenosis and related limb ischemia conditions.

\section{Treatment for patients with coronary artery restenosis}

Percutaneous coronary intervention was a major and minimally invasive way to treat coronary artery disease. However, cell hyperproliferation of local artery after percutaneous coronary intervention may result in lumen narrowing, ${ }^{50}$ which limited the use of this technology. The recent development of paclitaxel was considered as one of the most promising ways for reducing restenosis. Paclitaxel at a dose of $175 \mathrm{mg} /$ $\mathrm{mm}^{2}$ is recommended for tumor therapy, a broad range of doses $\left(1.3-10 \mu \mathrm{g} / \mathrm{mm}^{2}\right)$ is found to be safe and efficacious for reducing restenosis. ${ }^{51}$ In a randomized study it was demonstrated that restenosis occurred at a lower rate in patients with high-dose paclitaxel stents than those receiving low-dose paclitaxel stents at 6 months. ${ }^{52}$ After 9 months follow-up, the rate of angiographic restenosis was significantly reduced by paclitaxel-eluting stent. ${ }^{12}$ Gershlick et $\mathrm{al}^{53}$ reported that the angiographic indicators of in-stent restenosis were reduced without short-term or medium-term side effects by paclitaxelcoated stents at a dose density of $2.7 \mu \mathrm{g} / \mathrm{mm}^{2}$. Furthermore, Milewski et al ${ }^{54}$ demonstrated that paclitaxel-coated balloons had a dose (1-3 $\left.\mu \mathrm{g} / \mathrm{mm}^{2}\right)$-dependent effect on the inhibition of neointimal proliferation. Byrne et $\mathrm{al}^{55}$ investigated the efficacy among PEBs, PESs, and balloon angioplasty in restenosis patients; the results indicated that PEB could be a useful treatment. Mechanically, the smooth muscle cell cycle was interrupted by low dose paclitaxel via stabilizing microtubules, thereby arresting mitosis. ${ }^{53,56}$ However, Pires et $\mathrm{al}^{57}$ demonstrated high dose $(53.5 \mu \mathrm{g})$ paclitaxel-eluting cuffs had adverse vascular pathology and transcriptional responses. Hence, low dose paclitaxel is better than high dose paclitaxel for reducing restenosis.

\section{Conclusion}

Recent research from both clinical trials and preclinical work in animal models has demonstrated the therapeutic effects of paclitaxel in several non-cancer diseases. While some of the effects depend on the tubulin-stabilizing action of paclitaxel, others apparently may not. Further investigation is needed to gain insights into the cellular and molecular 
mechanisms of the effects of paclitaxel in various disease conditions. A thorough understanding of the actions and targets of paclitaxel within a cell would guide the design of therapies with efficacy and specificity. High dose paclitaxel induces inflammation and partly organ fibrosis, hence, before clinical application of paclitaxel, we need to carefully assess what dose is safe.

\section{Acknowledgments}

The study was supported in part by grants from National Natural Science Foundation of China [81370791; 81100507] and the National Institutes of Health and Department of Veterans Administration of USA.

\section{Disclosure}

The authors report no conflicts of interest in this work.

\section{References}

1. Goldspiel BR. Clinical overview of the taxanes. Pharmacotherapy. 1997; 17:110S-125S.

2. Ledwitch K, Ogburn R, Cox J, et al. Taxol: efficacy against oral squamous cell carcinoma. Mini Rev Med Chem. 2013;13:509-521.

3. Rowinsky EK. The development and clinical utility of the taxane class of antimicrotubule chemotherapy agents. Annu Rev Med. 1997;48:353-374.

4. Mekhail TM, Markman M. Paclitaxel in cancer therapy. Expert Opin Pharmacother. 2002;3(6):755-766.

5. Zhou J, Zhong DW, Wang QW, et al. Paclitaxel ameliorates fibrosis in hepatic stellate cells via inhibition of TGF- $\beta /$ Smad activity. World J Gasteroenterol. 2010;16(26):3330-3334.

6. Liu X, Zhu S, Wang T, et al. Paclitaxel modulates TGF- $\beta$ signaling in scleroderma skin grafts in immunodeficient mice. PLoS Med. 2005;2(12):e354.

7. Zhang D, Sun L, Xian W, et al. Low-dose paclitaxel ameliorates renal fibrosis in rat UUO model by inhibition of TGF- $\beta /$ Smad activity. Lab Invest. 2010;90(3):436-447.

8. Sun L, Zhang D, Fuyou Liu, et al. Low-dose paclitaxel ameliorates fibrosis in the remnant kidney model by down-regulating miR-192. J Pathol. 2011;225(3):364-377.

9. Mirzapoiazova T, Kolosova IA, Moreno L, Sammani S, Garcia JG, Verin AD. Suppression of endotoxin-induced inflammation by paclitaxel. Eur Respir J. 2007;30(3):429-435.

10. Hellal F, Hurtado A, Ruschel J, et al. Microtubule stabilization reduces scarring and causes axon regeneration after spinal cord injury. Science. 2011;331(6019):928-931.

11. Tepe G, Zeller T, Albrecht T, et al. Local delivery of paclitaxel to inhibit restenosis during angioplasty of the leg. $N$ Engl J Med. 2008;358(7): 689-699.

12. Stone GW, Ellis SG, Cox DA, et al. A polymer-based, paclitaxeleluting stent in patients with coronary artery disease. $N$ Engl J Med. 2004;350(3):221-231.

13. Bharadwaj R, Yu H. The spindle checkpoint, aneuploidy, and cancer. Oncogene. 2004;23(11):2016-2027.

14. Brito DA, Yang Z, Rieder CL. Microtubules do not promote mitotic slippage when the spindle assembly checkpoint cannot be satisfied. The Journal of Cell Biology. 2008;182(4):623-629.

15. Jordan MA, Wilson L. Microtubules as a target for anticancer drugs. Nat Rev Cancer. 2004;4(4):253-265.

16. Ganguly A, Yang H, Cabral F. Paclitaxel-dependent cell lines reveal a novel drug activity. Mol Cancer Ther. 2010;9(11):2914-2923.
17. Löwe J, Li H, Downing KH, et al. Refined structure of alpha beta-tubulin at 3.5 A resolution. $J$ Mol Biol. 2001;313(5):1045-1057.

18. Panis C, Lemos LG, Victorino VJ, et al. Immunological effects of taxol and adryamicin in breast cancer patients. Cancer Immunol Immunother. 2012;61(4):481-488.

19. Alexandre J, Hu Y, Lu W, Pelicano H, Huang P. Novel action of paclitaxel against cancer cells: bystander effect mediated by reactive oxygen species. Cancer Res. 2007;67(8):3512-3517.

20. Hadzic T, Aykin-Burns N, Zhu Y, et al. Paclitaxel combined with inhibitors of glucose and hydroperoxide metabolism enhances breast cancer cell killing via $\mathrm{H} 2 \mathrm{O} 2$-mediated oxidative stress. Free Radic Biol Med. 2010;48(8):1024-1033.

21. Sevko A, Michels T, Vrohlings M, et al. Antitumor effect of paclitaxel is mediated by inhibition of myeloid-derived suppressor cells and chronic inflammation in the spontaneous melanoma model. J Immunol. 2013;190(5):2464-2471.

22. Sevko A, Kremer V, Falk C, et al. Application of paclitaxel in low non-cytotoxic doses supports vaccination with melanoma antigens in normal mice. J Immunotoxicol. 2012;9(3):275-281.

23. Gan L, Chen S, Wang Y, et al. Inhibition of the androgen receptor as a novel mechanism of taxol chemotherapy in prostate cancer. Cancer Res. 2009;69(21):8386-8394.

24. Derynck R, ZhangYE. Smad-dependent and Smad-independent pathways in TGF-beta family signalling. Nature. 2003;425(6958):577-584.

25. Dong C, Li Z, Alvarez R, et al. Microtubule binding to Smads may regulate TGF beta activity. Mol Cell. 2000;5(1):27-34.

26. Brahn E, Tang C, Banquerigo ML. Regression of collagen-induced arthritis with Taxol, a microtubule stabilizer. Arthritis Rheum. 1994;37(6):839-845.

27. Karbalay-Doust S, Noorafshan A, Pourshahid SM. Taxol and taurine protect the renal tissue of rats after unilateral ureteral obstruction: a stereological survey. Korean J Urol. 2012;53(5):360-367.

28. Wang C, Song X, Li Y, et al. Low-dose paclitaxel ameliorates pulmonary fibrosis by suppressing TGF- $\beta 1 /$ Smad 3 pathway via miR-140 upregulation. PLoS One. 2013;8(8):e70725.

29. Tsukada T, Fushida S, Harada S, et al. Low-dose paclitaxel modulates tumour fibrosis in gastric cancer. Int J Oncol. 2013;42(4): 1167-1174.

30. Kupfer I, Balguerie X, Courville P, et al. Scleroderma-like cutaneous lesions induced by paclitaxel: a case study. J Am Acad Dermatol. 2003;48(2):279-281.

31. Eisenbeilss C, Weizel J, Wolff H. Scleroderma-like skin changes following administration of paclitaxel for the treatment of ovarian carcinoma. J Dtsch Dermatol Ges. 2003;1(6):468-470.

32. Ostoros G, Pretz A, Fillinger J, et al. Fatal pulmonary fibrosis induced by paclitaxel: a case report and review of the literature. Int $J$ Gynecol Cancer. 2006;16(1):391-393.

33. Sako T, Burioka N, Watanabe M, et al. [A case of stage IV advanced lung adenocarcinoma treated effectively using paclitaxel with the fibrosing radiographically on the chest CT]. Gan To Kagaku Ryoho. 2001;28(7):989-992. Japanese.

34. Petrache I, Birukova A, Ramirez SI, Garcia JG, Verin AD. The role of the microtubules in tumor necrosis factor-ainduced endothelial cell permeability. Am J Respir Cell Mol Biol. 2003;28(5):574-581.

35. Birukova AA, Smurova K, Birukov KG, et al. Microtubule disassembly induces cytoskeletal remodeling and lung vascular barrier dysfunction: role of Rho-dependent mechanisms. J Cell Physiol. 2004;201(1): $55-70$.

36. Kielbassa K, Schmitz C, Gerke V. Disruption of endothelial microfilaments selectively reduces the transendothelial migration of monocytes. Exp Cell Res. 1998;243(1):129-141.

37. Roberts RL, Nath J, Friedman MM, Gallin JI. Effects of taxol on human neutrophils. J Immunol. 1982;129(5):2134-2141.

38. Lee M, Jeon YJ. Paclitaxel-Induced Immune Suppression is sociated with NF- $\mathrm{KB}$ Activation Via Conventional PKC Isotypes in Lipopolysaccharide-Stimulated 70Z/3 Pre-B Lymphocyte Tumor Cells. Mol Pharmacol. 2001;59(2):248-253. 
39. Byrd CA, Bornmann W, Erdjument-Bromage H, et al. Heat shock protein 90 mediates macrophage activation by Paclitaxel and bacterial lipopolysaccharide. Proc Natl Acad Sci U S A. 1999;96(10):5645-5650.

40. Lee M, Yea SS, Jeon YJ. Paclitaxel causes mouse splenic lymphocytes to a state hyporesponsive to lipopolysaccharide stimulation. Int $J$ Immunopharmacol. 2000;22(8):615-621.

41. Shimazu R, Akashi S, Ogata H, et al. MD-2, a molecule that confers lipopolysaccharide responsiveness on toll-like receptor 4. J Exp Med. 1999; 189 (11):1777-1782.

42. Zimmer SM, Liu J, Clayton JL, et al. Paclitaxel binding to human and murine MD-2. J Biol Chem. 2008;283(41):27916-27926.

43. Resman N, Gradisar H, Vasl J, et al. Taxanes inhibit human TLR4 signaling by binding to MD-2. FEBS Lett. 2008;582(28): 3929-3934.

44. Zhang D, Li Y, Liu Y, et al. Paclitaxel ameliorates lipopolysaccharideinduced kidney injury by binding myeloid differentiation protein-2 to block Toll-like receptor 4-mediated nuclear factor- $\mathrm{\kappa B}$ activation and cytokine production. J Pharmacol Exp Ther. 2013;345(1):69-75.

45. Sengottuvel V, Leibinger M, Pfreimer M, Andreadaki A, Fischer D. Taxol Facilitates Axon Regeneration in the Mature CNS. J Neurosci. 2011;31(7):2688-2699.

46. Werk M, Langner S, Reinkensmeier B, et al. Inhibition of restenosis in femoropopliteal arteries: paclitaxel-coated versus uncoated balloon: femoral paclitaxel randomized pilot trial. Circulation. 2008;118(13): 1358-1365.

47. Siablis D, Karnabatidis D, Katsanos K, Diamantopoulos A, Christeas N, Kaqadis GC. Infrapopliteal application of paclitaxel-eluting stents for critical limb ischemia: midterm angiographic and clinical results. JVasc Interv Radiol. 2007;18(11):1351-1361.

48. Schmidt A, Piorkowski M, Werner M, et al. First experience with drugeluting balloons in infrapopliteal arteries: restenosis rate and clinical outcome. J Am Coll Cardiol. 2011;58(11):1105-1109.
49. Cafasso D, Schneider P. How paclitaxel can improve results in diabetics. J Cardiovasc Surg (Torino). 2012;53(1):13-21.

50. Indolfi $\mathrm{C}$, Coppola $\mathrm{C}$, Torella $\mathrm{D}$, Arcucci $\mathrm{O}$, Chiariello M. Gene therapy for restenosis after balloon angioplasty and stenting. Cardiol Rev. 1999;7(6):324-331.

51. Gunnar Tepe, Bruno Scheller, Ulrich Speck. Paclitaxel-coated angioplasty catheters for local drug delivery. Diagn Interv Radiol. 2007;13(2):61-63.

52. Park SJ, Shim WH, Ho DS, et al. A paclitaxel-eluting stent for the prevention of coronary restenosis. N Engl J Med. 2003;348(16): $1537-1545$.

53. Gershlick A, De Scheerder I, Chevalier B, et al. Inhibition of restenosis with a paclitaxel-eluting, polymer-free coronary stent: the European evaLUation of pacliTaxel Eluting Stent (ELUTES) trial. Circulation. 2004;109(4):487-493.

54. Milewski K, Afari ME, Tellez A, et al. Evaluation of efficacy and dose response of different paclitaxel-coated balloon formulations in a novel swine model of iliofemoral in-stent restenosis. JACC Cardiovasc Interv. 2012;5(10):1081-1088.

55. Byrne RA, Neumann FJ, Mehilli J, et al. Paclitaxel-eluting balloons, paclitaxel-eluting stents, and balloon angioplasty in patients with restenosis after implantation of a drug-eluting stent (ISAR-DESIRE 3): a randomised, open-label trial. Lancet. 2013;381(9865):461-467.

56. Sonoda S, Honda Y, Kataoka T, Bonneau HN, et al. Taxol-based eluting stents from theory to human validation: clinical and intravascular ultrasound observations. J Invasive Cardiol. 2003;15(3):109-114.

57. Pires NMM, Eefting D, de Vries MR, Quax PHA, Jukema JW. Sirolimus and paclitaxel provoke different vascular pathological responses after local delivery in a murine model for restenosis on underlying atherosclerotic arteries. Heart. 2007;93(8):922-927.
Drug Design, Development and Therapy

\section{Publish your work in this journal}

Drug Design, Development and Therapy is an international, peerreviewed open-access journal that spans the spectrum of drug design and development through to clinical applications. Clinical outcomes, patient safety, and programs for the development and effective, safe, and sustained use of medicines are a feature of the journal, which

\section{Dovepress}

has also been accepted for indexing on PubMed Central. The manuscript management system is completely online and includes a very quick and fair peer-review system, which is all easy to use. Visit $\mathrm{http}: / / \mathrm{www}$. dovepress.com/testimonials.php to read real quotes from published authors.

Submit your manuscript here: http://www.dovepress.com/drug-design-development-and-therapy-journal 